\title{
Medical Tourism Management Challenges - The Case of Dental Tourism in Albania
}

\author{
Dr. Olta Nexhipi \\ "Aleksander Moisiu" University, Durres, Albania
}

\begin{abstract}
This study explores the factors that attract clients, Albanian emigrants and foreigners, to profit from dental services in Albania. There are many factors that determine the decision to choose Albanian dental services in Albania and not in their respective residence countries. This paper examines data concerning factors that influence clients' choice. Additionally, this research provides information about the main tools that dental tourists use to choose whether to have dental services in their respective residence country or in Albania. The factors that have been analyzed are: Quality, Price, Hygiene, Environment, Customer Care, Customer Behavior, Places to visit. Data helps in developing a strategy that attracts foreign customers and Albanian emigrants to benefit from dental services in Albania. Finally this study gives a picture of the actual promotion of dental services and further recommendation in order to attract more customers are provided, taking into consideration that the quality offered is competitive in Balkans.
\end{abstract}

Keywords: dental tourism, dentistry services, tourism strategy, customer behavior.

\section{Introduction}

Albania is transforming in a major tourist destination. The number of tourists is growing rapidly each year and tourism sector is booming. There are many reasons why tourists visit a country; culture, wildlife, relax, etc. According to INSTAT ${ }^{1}$ tourists visit Albania for vacations, visiting friends and family, daily visit, heath tourism, and religious purposes.

In 2006 there was a new term that entered in the field of tourism, medical Tourism. Even though the term was created in 2006, this does not mean that medical tourism did not exist as a concept before. People used to travel also in ancient periods for medical reasons, as an example thermal water traveling can be mentioned.

In fact, archaeological evidence from the third millennium B.C. suggests that people in ancient Mesopotamia traveled to the temple of a healing god or goddess at Tell Brak, Syriato heal eye disorders. A couple millennia later the Greeks and Romans would travel by foot or boat to SPAS and cult centers all over the Mediterranean. The Asclepia Temples, dedicated in honor of the Greek god of medicine, were some of the world's first healing centers. Pilgrims would come and stay several nights praying that Asclepios would appear in a dream and provide a cure to their ailment. ${ }^{2}$

In 2006 medical tourism started to be a very popular term because medical journals started to use the concept, as a profiting one for both developing and industrial countries. In such conditions countries started to invest in medicine in order to attract more tourist and to bring more income to the country. A medical tourist is someone who travels abroad with the purpose of reducing his medical costs. Globalization and technology helps patients to be informed, this is why companies that offer health treatments invest in emerging industry to offer a dental medical infrastructure that will attract foreigners and will create income for the business and for the country.

According to (J. L. Weis, R. B. Sirard, P. A. Palmieri, 2017) the number of people that travel for medical purposes is difficult to be calculated. Approximately estimated 50 million patients travel abroad each year to receive medical services and 3$20 \%$ of Europeans receive treatment in another European Union country. The main reasons given by health tourists is the short waiting time and the lower costs.

According to a study made by Deloitte Consulting, 750,000 resident Americans travel abroad for health service in 2007. And this number continued to increase and reached 1.6 million people by 2012. The same phenomena happens with people leaving in the European Union. Based on this, health tourism is not a phenomena of countries that have poor healthcare but is a phenomena of choice. People mostly travel abroad for cosmetic reasons but there are also cases when they travel

\footnotetext{
1 Institution of statistics in Albania

2 http://medicaltourism.com/Forms/facts-statistics.aspx
} 
for other needed surgeries like organ transplant or fertilization, which in some countries is not even allowed. Especially in the Muslim countries where fertilization is controlled case by case based on the countries law 1 .

Albania is a country which in the last five years has an increasing number of visitors. People that travel to Albania for health care purposes mostly travel for dental care. According to the Medical dental Association, dental tourism is the act of a person traveling from one country to another for dental care. While in Europe dental tourism is commonly known as dental vacations or dental holidays. Data collected in the framework of this study shows that Albania is a country that has shown the potential of satisfying tourists in the field of dental tourism.

The main research objectives of this study are: to provide an overview of main reasons why Albania should be a considered as a destination in the field of dental Tourism, second to analyze the satisfaction of Albanians and foreigners in the dental care and finally it aims to present the areas that need improvement in order to attract tourists. This study is of a descriptive nature, because through descriptive statistics we have analyzed the data and come to conclusions.

\section{General information about Albanian Dental System}

Dental Tourism is offered all over the world and there are many countries that offer good quality for a very good prices. Here we come to the question why tourist should visit Albania. Which has many answers;

Education - in Albania the universities in which dentists study do use the latest technology in education and in practice for the students. The Albanian Law obliges students of dentistry to follow at least three international conferences in European Countries, on the technology development otherwise they cannot finish their study. This helps students to constantly improve they know-what and know-how in order to gain knowledge about the newest dental techniques.

Technology - according to the dentists association in Albania, the technology used by Albanian dentists is the latest developed one, and the investment in the field of dentistry is high.It can be compared to the technology of the most developed countries².

Albanian Tourism - Albania is a country that can offer four seasons tourism due to its geographical position and on its climate. In the last five years the number of tourist visiting Albania has been increasing, especially the number of tourists from European countries near Albania, like Italy or Greece. According to the Italian news agency, RAl Albania offer low prices, fresh food and a spectacular nature, this is the reason why the number of Italian visitors in Albania was 50.000 . In figure 1 is shown the number of foreigners visiting Albania from 2012 to 2016, we notice that Albania has been visited by tourists from Africa, Amerika, East Asia and Pacific, Middle East, South Asia and Europe, the highest number of tourists come from Central Europe, Northern Europe, Southern Europe, Western Europe and East/Mediterranean Europe.

\begin{tabular}{|l|l|l|l|l|l|}
\hline Description & 2012 & 2013 & 2014 & 2015 & 2016 \\
\hline Africa & 1,057 & 919 & 859 & 2,973 & 1,077 \\
\hline America & 73,810 & 73,291 & 90,084 & 96,763 & 103,839 \\
\hline East Asia and Pacific & 19,689 & 23,628 & 30,874 & 33,032 & 35,894 \\
\hline Middle East & 1,524 & 3,944 & 2,607 & 3,604 & 4,324 \\
\hline South Asia & 1,135 & 961 & 1,274 & 1,636 & 1,699 \\
\hline Central /Eastern Europe & 90,643 & 112,333 & 163,006 & 151,457 & 182,581 \\
\hline - Northern Europe & 117,434 & 119,016 & 137,308 & 125513 & 149,965 \\
\hline - Southern Europe & $2,759,374$ & $2,467,195$ & $2,821,920$ & 3169174 & $3,855,617$ \\
\hline - Western Europe & 200,462 & 210,845 & 237,760 & 246,811 & 221,492 \\
\hline - East/ Mediterranean Europe & 46,198 & 54,194 & 63,671 & 66,468 & 75,750 \\
\hline
\end{tabular}

Figure 1. Tourist visiting Albania during the period 2012-2016

(Source; Institution of Statistics Albania ${ }^{3}$ )

\footnotetext{
1 https://www.al-islam.org/marriage-and-morals-islam-sayyid-muhammad-rizvi/chapter-five-new-techniques-humanreproduction\#f_ca6a9f22_5 (Accessed, October 2017)

2 http://www.shdsh.org/PerProfesionistet/Legjislacion.aspx

${ }^{3}$ http://databaza.instat.gov.al/pxweb/sq/DST/START TU/
} 
Based on the facts given previously the number of tourists visiting Albania keeps increasing. The institution of statistics makes also a division on the reasons why tourist visit Albania. Data from the years 2012-2015 show that the reasons why tourists enter Albania are holidays, visits to friends and relatives, health treatment, religious reasons, transit, one day visits and other reasons which are not specifies.

\begin{tabular}{|l|l|l|l|l|}
\hline Description & 2012 & 2013 & 2014 & 2015 \\
\hline Visitors & $3,226,460$ & $3,077,691$ & $3,467,765$ & $3,945,937$ \\
\hline Holidays & $1,492,898$ & 484,018 & $1,315,409$ & $1,579,252$ \\
\hline Visit to friends and relatives & 89,999 & 33,904 & 37,345 & 32,537 \\
\hline Health treatment & 1,188 & 1,083 & 1,503 & 1,554 \\
\hline Religious & 1,501 & 1,108 & 2,543 & 1,600 \\
\hline Transit & 287,206 & 178,297 & 204,826 & 185,305 \\
\hline One-day visits & 71,292 & 220,265 & 126,691 & 161,580 \\
\hline Other reasons & $1,527,615$ & $2,287,450$ & $1,936,105$ & $2,127,277$ \\
\hline Business & 41,967 & 49,863 & 48,169 & 42,137 \\
\hline
\end{tabular}

Figure 2. Arrivals of foreigners in Albania by purpose of travel, 2012-2015. (Source; Institution of Statistics Albania')

As we notice from the table the number of tourists visiting Albania for health care purpose has been increased with the passing of the years and we can also notice it from the figure 3 .

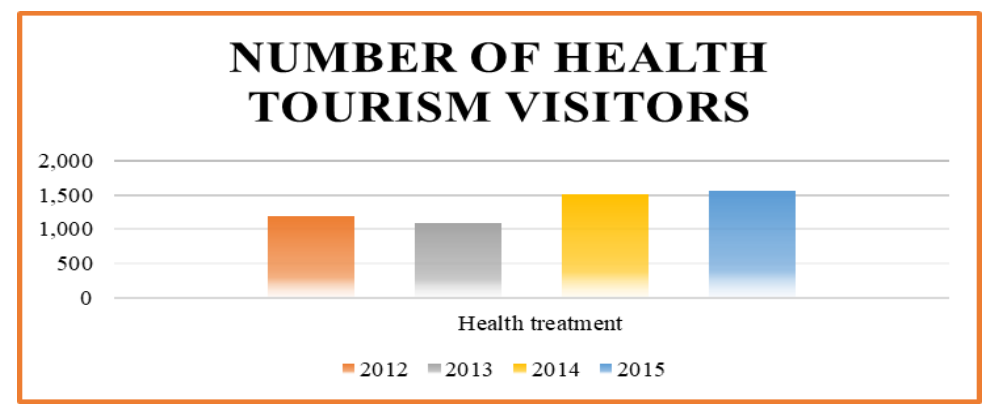

Figure 3. Health tourists Visitors in Albania In years

(Source; Institution of Statistics Albania2)

The main objective of this study is to determine how the potential of Albania in tourism can be fruitful even for dental tourism. This objective is achieved through the analysis of the data collected from potential clients that do not reside in Albania.

\section{Methodology}

An online questionnaire was distributed from August 2017 to November 2017, it was developed after literature review and discussions with colleges in the Institution of statistics in Albania. The distributed questionnaire was divided in two sections. Section one collected demographic data while section two has direct questions on dental treatments that tourists had in Albania and about the perception of tourists on service and their reaction after the treatment (like word of mouth).

The questionnaire was distributed online to 100 respondents, and many of the questions on the questionnaire were mandatory. 60 questionnaires were completed by Albanian emigrants and foreigners that visit Albania while the difference

\footnotetext{
1 http://databaza.instat.gov.al/pxweb/sq/DST/START_TU/

2 http://databaza.instat.gov.al/pxweb/sq/DST/START TU/
} 
was distributed to Albanian people in order to see their perception on the service they have and if they would advise the service to foreign people they know and they have contact.

Through a question in the questionnaire we had the consent from participants in order to participate in the study. They were assured that refusal would not lead to any adverse consequences and the answers would be confidential and they would be used only for study purposes.

This is a descriptive study. Descriptive studies are aimed at finding out "what is," so observational and survey methods are frequently used to collect descriptive data (Borg \& Gall, 1989). Descriptive research is unique in the number of variables employed. Like other types of research, descriptive research includes multiple variables for analysis, yet unlike other methods, it requires only one variable (Borg \& Gall, 1989).

\section{Results}

Out of 100 forms that were distributed, 100 were completed, returned and analyzed (response rate 100\%). They were computed by Albanians and foreigners. The mean age of respondents was 38 years. The highest percentage of respondents were female (67.5\%) and males (32.5\%). $91 \%$ of respondents visit Albania one two three times a year. Their countries of residence are: Albania ( $40 \%$ of respondents), Italy (25\% of respondents), Greece ( $9 \%$ of respondents), United States of America (5\% of respondents), Germany (10\% of respondents) and Switzerland ( $7 \%$ of respondents). There is also a category of other countries in which respondents were from Serbia and Kosovo ( $4 \%$ of respondents).

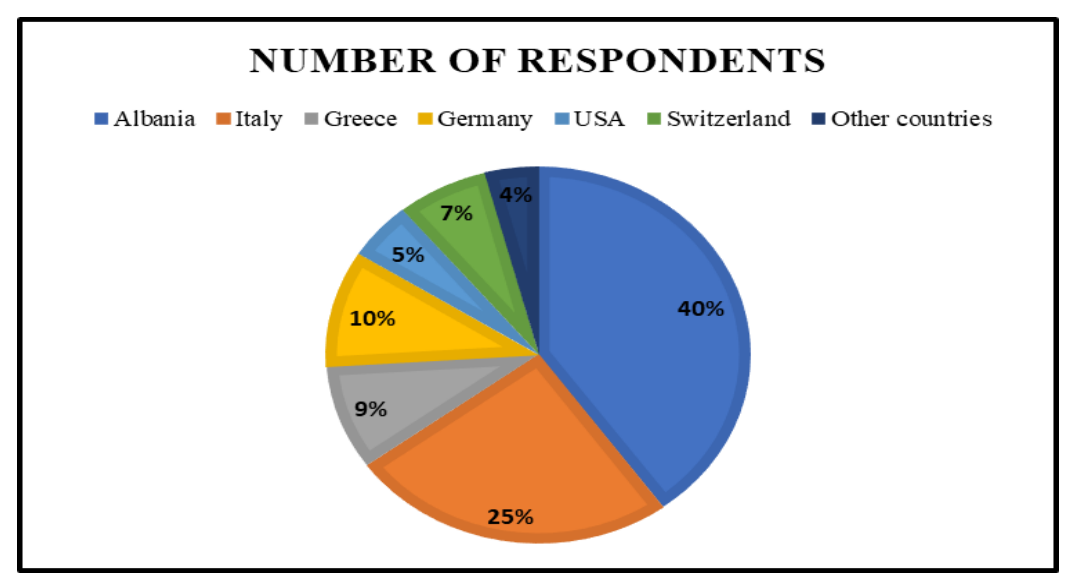

Figure 4. Number of respondents by country

During their visit to Albania $91 \%$ of respondents have tried dental care and only $85 \%$ of them were satisfied with the treatment and service. The reasons of choosing Albania were: an immediate need, like they felt bad and it was a necessity ( $12 \%$ of the respondents); low price ( $50 \%$ of the respondents); good service ( $24 \%$ of the respondents); good hygienic conditions ( $4 \%$ of respondents); quality offered ( $10 \%$ of respondents). 


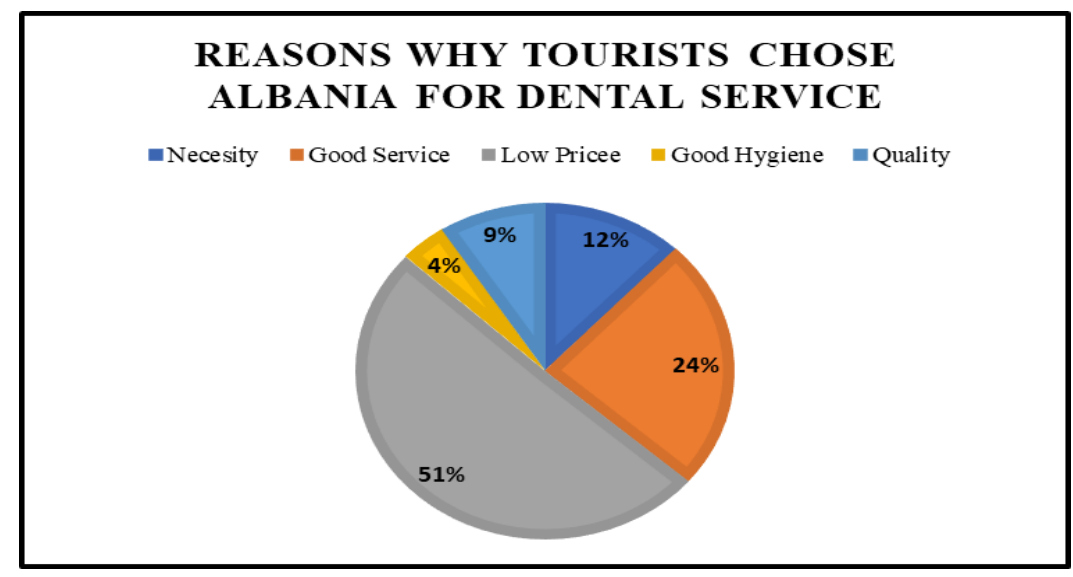

Figure 5. Reasons why tourists chose to profit from dental Service in Albania. Answers in percentage.

The main factor that determine dental tourists choice are convenient price and quality service. $75 \%$ of the respondents that took dental service in Albania have recommended their foreign friends to visit Albania and to profit from the dental service it offers. $62 \%$ of the respondents say that they have advised dental tourism in Albania to 1 to 3 foreigners they know.

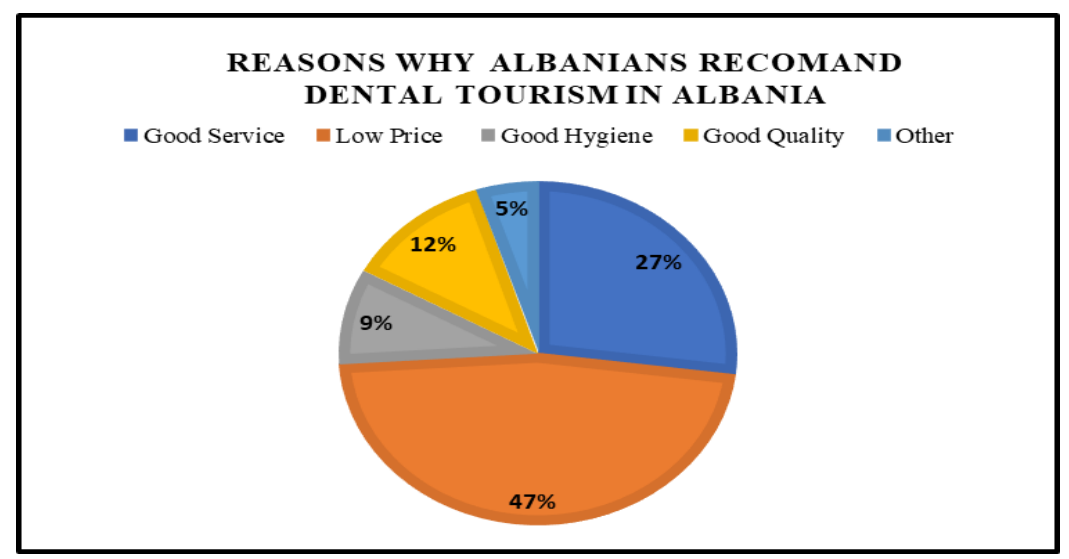

Figure 6. Reasons why people that leave abroad advice dental service in Albania. Answers in percentage.

As we can see from figure 6 the main elements that people living abroad and that have tried dental service in Albania are quality service and convenient price. Respondents recommended other elements that Albanian tourism can offer such as visiting museums, enjoying seaside or hiking and sightseeing in the mountains.

The second part of the study was directed to the Albanians that take a continuous dental care in Albania. Respondents gave their personal evaluation of the dental care in Albania through Likert Scale questions. 


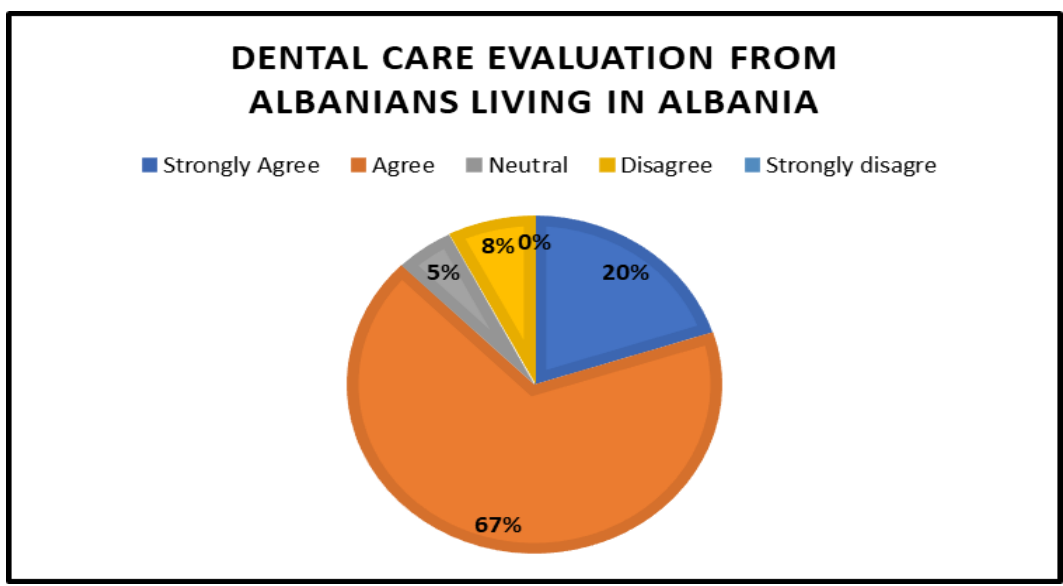

Figure 7. How Albanians evaluate the dental care in their country.

\section{Answers in percentage.}

There is a paradox in the finding, zero percent of people evaluate dental service in Albania as bad and only $5 \%$ of them agree with the fact that dental service can be considered as bad. While $67 \%$ of the 40 respondents consider the dental care in Albania as a good service.

\section{Conclusions and Discussions}

The sample size of this study was relatively small related to the health tourists that visit Albania but still it helps to create an idea about the opinion that tourists have on the dental care in Albania.

Nevertheless it revealed some interesting findings. Women travelled for dental care more than man. The overall mean age was 38 years which means that people tend to seek dental care in Albania while they are young. The biggest number of respondents was from Albania, Italy, and Germany.

While dental tourists may possibly travel for an array of reasons, their choices are usually motivated by price considerations. This was also revealed by the results of the study, people travel to Albania for dental care due to low price. And they advise it to other people due to low price. Quality is an element that attracts people to come to Albania for dental care, and in the meantime based on the questionnaires Albanians that live in Albania consider the dental service as a good one and there is no one that thinks dental service is absolutely bad.

Based on the data collected and on the literature, some recommendations can be given to dentist to attract more dental tourists

Keep on with same prices- evaluate their pricing policy

Keep quality by being in touch with technology and dental techniques- continuously improve their quality and update their technology

Contact tourism agencies and offer their prices in order to create packets for dental care and tourism- build partnership with tourism agencies

Make more promotions to the services their offer- focus on their marketing and promotion strategies

Education and traveling abroad of dentists should be intensified-training and capacity building of dentists should be intensified. 
Dental tourism has a lot of potential of future development and it can be within the core priorities of the development of medical tourism policies. Awareness can be raised through the various channels of communication among all age groups in the community.

\section{Limitations}

The limitations of this study include scarcity of data and statistics on patients who travelled for dental treatment; this resulted in a small sample size. A further limitation is the shortage of scientific literature about medical tourism in Albania. Further studies in these various countries, individually or as multicenter studies, are required to obtain a clearer picture of the dental treatment in Albania.

\section{References}

[1] Bouvier PA. Medical tourism: A new kind of traveler. Rev Med Suisse 2008; 4:1196, 1198-201.

[2] Horowitz, M. D. and Rosenweig, J. A. (2007) 'Medical Tourism: Globalization of the Healthcare Marketplace', Medscape General Medicine Journal, Vol. 9 (4)

[3] Jamie L Weis, R Barry Sirard, Patrick A Palmieri, (2016) "Medical tourism: the role of the primary care provider", BJGP Open, 1-4.

[4] Johnston R, Crooks VA, Snyder J, Kingsbury P. What is known about the effects of medical tourism in destination and departure countries? A scoping review. Int J Equity Health 2010; 9:24.

[5] Kovacs E, Szocska G. Vacation for your teeth: Dental tourists in Hungary from the perspective of Hungarian dentists. Br Dent J 2013;215:415-8.

[6] Porter, M. E. (1998) 'The competitive advantage of nations', Basingstoke; The Macmillan

[7] Turner L. Medical tourism: Family medicine and international health-related travel. Can Fam Physician 2007; 53:1639-41, 1646-8.

[8] Zoltan, J. and Maggi, M. "What is Tourism in dental tourism", Institution of economic research, Press, London

[9] Medical Tourism Consumers in Search of Value. Deloitte Center for Health Solutions. From:http://www.deloitte.com/assets/Dcom- UnitedStates/Local\%20Assets/Documents /us_chs_ MedicalTourismStudy(3).pdf. Accessed: November 2017.

[10] Available from: http://www.dentachoicehome.com/images/.../dental/pdf/Dental\%20Tourism.pdf. Accessed: November 2017 